\title{
Mechanical Properties of Sulfonated Poly (Ether Ether Ketone) Nanocomposite Membranes
}

\author{
S. Sonpingkam and D. Pattavarakorn
}

\begin{abstract}
Sulfonated poly (ether ether ketone), SPEEK nanocomposite membranes were prepared and their mechanical properties were investigated. The commercial poly(ether ether ketone), Victrex PEEK@ was sulfonated with concentrated sulfuric acid $(96 \mathrm{v} / \mathrm{v} \%)$ at $50{ }^{\circ} \mathrm{C}$ for various sulfonation times (4-8 hrs) to obtain SPEEK with various degrees of sulfonation (DS) and ion exchange capacity (IEC). Furthermore, SPEEK nanocomposite membranes were prepared via solution casting method. The effects of nanofiller type (nanosilicon dioxide, nanotitanium dioxide and nanotungsten trioxide) and nanofiller concentration to the properties of the nanocomposite membranes were examined. The results indicated that the DS and IEC values of SPEEKs increased with sulfonation time. Moreover, it was found that the mechanical properties of SPEEK nanocomposite membranes significantly depended on nanofiller type, concentration and their distribution.
\end{abstract}

Index Terms-Poly (ether ether ketone), PEEK, sulfonation, nanocomposite, membrane.

\section{INTRODUCTION}

Direct methanol fuel cell (DMFC) is a type of proton exchange membrane fuel cell (PEMFC) that generates electricity using liquid methanol as a fuel [1]. Direct methanol fuel cell is suitable for portable devices or transportation applications due to the fact of their high energy density and the ease of handling a liquid fuel, etc. [2].

The proton exchange membrane (PEM) commonly used in DMFC is a perfuorosulfonic acid-type electrolyte membranes, Nafion ${ }^{\circledR}$ as a typical example. However, although they show superior performance in fuel cells, large-scale applications of these membranes are limited by their high cost and poor barrier to methanol crossover [3]. The methanol transport from anode to cathode causes the oxidation reaction to take place not only in anode but also cathode, resulting in low efficiencies, mixed potential, and loss of fuel.

Sulfonated poly(ether ether ketone) (SPEEK) membrane has a potential to be used in DMFC [4]-[7], which due to its high mechanical strength, high thermal stability, cheap, easily to handle, low methanol crossover and also moderate proton conductivity. Nevertheless, raw material for SPEEK membrane; poly(ether ether ketone) (PEEK), is a hydro-

Manuscript received September 9, 2013; revised November 21, 2013. This study was supported financially by the Center of Excellence in Materials Science and Technology, Faculty of Science and the Graduated School, Chiang Mai University.

The authors are with the Chiang Mai University, Faculty of science, Department of Industrial Chemistry, Chiang Mai 50200, Thailand (e-mail: datchanee.p@cmu.ac). phobic polymer and not suitable to fabricate as membrane. Therefore, PEEK has to be modified by the sulfonation process using concentrated sulfuric acid.

In recent years, some new proton exchange membranes (PEMs) have been successfully proposed such as polymer blend membranes [8]-[12] and polymer composite membranes. Several inorganic materials have been applied for this purpose such as montmorillonite [13], [14], silicon dioxide, titanium dioxide and zirconium oxide [4]. Preparation of such composite membrane systems may induce the enhancement of proton conductivity, reduction of methanol permeability and improvement of mechanical strength.

Organic-inorganic nanocomposites have attracted much interest as membrane for fuel cells, since inorganic nanoparticles in a polymer matrix might improve mechanical strength [15], [16], proton conductivity [16]-[18] fuel barrier properties [16], and membrane durability [16].

In this research, preparation of SPEEK nanocomposite membranes for direct methanol fuel cell application was studied. Poly (ether ether ketone) was sulfonated with sulfuric acid and then SPEEK nanocomposite membranes were prepared by casting method. The influences of degree of sulfonation (DS), nanofiller type and nanofiller contents to the membrane properties; chemical properties, physical properties, thermal properties and mechanical properties were investigated.

\section{EXPERIMENTAL}

\section{A. Materials}

Poly(ether ether ketone), PEEK samples (Vitrix $\left.{ }^{\circledR} 450 \mathrm{PF}\right)$ was purchased from ICI Company (Rotherham, UK) and used as received. Sulfuric acid (96\%, RCL labscan) was used for poly(ether ether ketone) sulfonation. Dimethylacetamide, DMAc (Aldrich) was used as a solvent for membrane casting. A commercial surfactant, Plurinic ${ }^{\circledR}$ L64 $\left(\mathrm{PEO}_{13}-\mathrm{PPO}_{30^{-}}\right.$ $\mathrm{PEO}_{13}$, BASF, Ludwigshafen, Germany) was used as a dispersant to distribute nanoparticles. Nanoparticle of $\mathrm{SiO}_{2}$ (Aerosil ${ }^{\circledR} 200$, surface area of $200 \mathrm{~m}^{2} \mathrm{~g}^{-1}$, average particle size $12 \mathrm{~nm}$ ), $\mathrm{TiO}_{2}\left(\right.$ Aeroxide ${ }^{\circledR} \mathrm{TiO}_{2} \mathrm{P} 25$, Nippon Aerosil Co.Ltd., average particle size $21 \mathrm{~nm}$ ) and $\mathrm{WO}_{3}$ (Aldrich, average particle size $<100 \mathrm{~nm}$ ) were used as nanofillers.

\section{B. Sulfonation of PEEK}

PEEK particles were first dried in a vacuum oven at $100^{\circ} \mathrm{C}$ for $2 \mathrm{~h}$. Then $10 \mathrm{~g}$ of PEEK was dissolved gradually in $400 \mathrm{~mL}$ of $96 \%$ sulfuric acid in a three-neck flask under 
nitrogen atmosphere and vigorously stirred at room temperature (about $1 \mathrm{~h}$ ). After that, the temperature of solution was controlled at $50{ }^{\circ} \mathrm{C}$ for a desired period between 4 and $8 \mathrm{~h}$. Then PEEK solution was poured into a large excess of ice water to precipitate the sulfonated poly(ether ether ketone), SPEEK. The precipitate SPEEK was collected by filtration and washed vigorously with distilled water until the $\mathrm{pH}$ became neutral. The precipitate SPEEK was then dried in an oven at $60{ }^{\circ} \mathrm{C}$ for $2 \mathrm{~h}$ and $100{ }^{\circ} \mathrm{C}$ for $24 \mathrm{~h}$. The chemical structure of SPEEKs was confirmed using the Fourier transform infrared spectroscopy (FTIR) to identify the presence of sulfonic acid group in the polymer samples. The spectra were measured in transmittance mode over a wave number range of $4000-600 \mathrm{~cm}^{-1}$.

\section{Determination of Degree of Sulfonation and Ion Exchange Capacity}

The degree of sulfonation is defined as the ratio of the molar number of sulfonated PEEK units to that of the total molar number of initial repeat units of PEEK. In this work, degree of sulfonation (DS) and ion exchange capacity (IEC) of SPEEK were determined by a titration method [19]. $0.1 \mathrm{~g}$ SPEEK was first immersed into $0.1 \mathrm{M} \mathrm{NaCl}$ solution for 24 $\mathrm{h}$ and then back titrated with $0.1 \mathrm{M} \mathrm{NaOH}$ using phenolphthalein as an indicator. Then the values of DS and IEC of SPEEK were obtained from equations (1) and (2).

$$
\begin{aligned}
& \mathrm{DS}=\left[N_{\mathrm{PEEK}_{-} \mathrm{SO}_{3} \mathrm{H}} /\left(N_{\mathrm{PEEK}_{-} \mathrm{SO}_{3} \mathrm{H}}+N_{\mathrm{PEEK}}\right)\right] \\
& \mathrm{IEC}=\left[N_{-\mathrm{SO}_{3} \mathrm{H}} / W_{\text {sample }} \times(1000)\right]
\end{aligned}
$$

where $N_{\mathrm{PEEK}_{-} \mathrm{SO}_{3} \mathrm{H}}$ and $N_{-\mathrm{SO}_{3} \mathrm{H}}$ are the molar number of sulfonated PEEK units and sulfonate groups, respectively. $N_{\text {PEEK }}$ is the molar number of unsulfonated PEEK units. $W_{\text {sample }}$ represents the sample weight. According to the expressions of DS and IEC, the molar number, $N_{\text {PEEK-SO }} \mathrm{H}$, of the sulfonated PEEK unit $\left(\mathrm{PEEK}-\mathrm{SO}_{3} \mathrm{H}\right)$ in $1 \mathrm{~g}$ sulfonated PEEK copolymer is:

$$
N_{\text {PEEK-SO }}{ }_{3} \mathrm{H}=[0.001 \times(\mathrm{IEC})]
$$

The molar number of PEEK unit in $1 \mathrm{~g}$ SPEEK copolymer is:

$$
N_{\mathrm{PEEK}}=\left[1-0.001 \times \mathrm{IEC} \times M_{\mathrm{PEEK}_{-\mathrm{SO}_{3} \mathrm{H}}} /\left(M_{\mathrm{PEEK}}\right)\right]
$$

where $M_{\text {PEEK-SO }}{ }_{3}$ and $M_{\text {PEEK }}$ are the molecular weights of PEEK-SO ${ }_{3} \mathrm{H}$ unit and PEEK unit, respectively. In which $M_{\mathrm{PEEK} \mathrm{SO}_{3} \mathrm{H}}=368 \mathrm{Da}$ and $M_{\mathrm{PEEK}}=288 \mathrm{Da}$ [19].

\section{Preparation of SPEEK Nanocomposite Membranes}

In order to fabricate SPEEK nanocomposite membranes, $1.2 \mathrm{~g}$ SPEEK (degree of sulfonation of $60 \%$ ) was dissolved in 38.8 g DMAc under nitrogen atmosphere and vigorously stirred at room temperature (about $25 \mathrm{~min}$ ). The solution was sonicated for $10 \mathrm{~min}$, various contents (1-5 wt.\%) of nanofillers $\left(\mathrm{SiO}_{2}, \mathrm{TiO}_{2}\right.$ and $\left.\mathrm{WO}_{3}\right)$ and 5 wt.\% of $\mathrm{L} 64$ surfactant were then poured in SPEEK solution. The mixtures were mechanically stirred for 1 day at room temperature. For membrane casting, the $10 \mathrm{~min}$ sonicated mixtures were cast on the glass dish and then dried at $80{ }^{\circ} \mathrm{C}$ for $17 \mathrm{~h}$ and $100^{\circ} \mathrm{C}$ for $2 \mathrm{~h}$.

\section{E. Characterization of SPEEK Nanocomposite Membranes}

\section{1) Morphology test}

The morphologies of nanocomposite membranes were investigated using FE-SEM technique (Jeol, JSM 6335F).

2) Crystallinity test

The crystallinity of nanocomposite membranes was examined with an X-ray diffraction, XRD (Rigaku Miniflex II desktop X-ray diffractometer). The membrane samples were scanned in the reflection mode with a $2 \theta$ angle between $5^{\circ}$ and $60^{\circ}$ with a scan rate of $0.05^{\circ} \mathrm{min}^{-1}$.

\section{3) Thermal stability test}

The degradation process and the thermal stability of nanocomposite membranes were investigated using thermogravimetry, TGA (Rigaku, TG 8120, Japan). $10 \mathrm{mg}$ of samples were loaded into an alumina pan and then heated from 100 to $700{ }^{\circ} \mathrm{C}$ at a rate of $10^{\circ} \mathrm{C} \mathrm{min}^{-1}$ in $\mathrm{N}_{2}$ flow.

\section{4) Mechanical properties test}

The mechanical properties were studied by tensile testing. The tensile properties of nanocomposite membranes were measured using a universal tensile machine according to ASTMD882. Membranes with $10 \mathrm{~mm}$ in width and $40 \mathrm{~mm}$ in length were tested with a $500 \mathrm{~N}$ load cell at the test speed of $2 \mathrm{~mm} / \mathrm{min}$.

\section{5) Water uptake test}

The membranes were dried at $60^{\circ} \mathrm{C}$ for $24 \mathrm{~h}$ in vacuum oven before measuring the dry membrane weight. The membranes were soaked in water for $24 \mathrm{~h}$ to promote water uptake up to equilibrium. Immediately after the membrane surface was wiped with a clean tissue to remove any trace of liquid, the membrane was weighed. The $\%$ water uptake was calculated by:

$$
W t \%=\left[\left(W_{\text {wet }}-W_{\text {dry }} /\left(W_{\text {dry }}\right)\right) \times 100 \%\right]
$$

where $W_{\text {wet }}$ and $W_{\text {dry }}$ are the weights of wet and dry membranes, respectively. The water uptake measurements were carried out at room temperature.

\section{RESUlTS AND DisCUSSION}

\section{A. Chemical Structure, Degree of Sulfonation and Ion Exchange Capacity}

PEEK was sulfonated with $96 \%$ sulfuric acid at $50{ }^{\circ} \mathrm{C}$ in order to improve its proton conductivity. The effects of sulfonation reaction time were investigated. Fig. 1 shows the FTIR spectra of PEEK and SPEEK with different degree of sulfonation. The absorption band at $704 \mathrm{~cm}^{-1}$ can be assigned to S-O stretching of sulfonic acid groups [20]. The new absorption bands at 1009,1074 and $1258 \mathrm{~cm}^{-1}$ of SPEEK identify the symmetric and asymmetric stretching vibrations of the sulfonic acid group [13]. The aromatic $\mathrm{C}-\mathrm{C}$ band at $1490 \mathrm{~cm}^{-1}$ for PEEK is observed to split into two peaks at 1476 and $1493 \mathrm{~cm}^{-1}$ for SPEEK, due to the new substitute from sulfonation [19]. The peak at $1655 \mathrm{~cm}^{-1}$ can be clearly 
observed due to the stretching of carbonyl groups [21]. The intensity of absorption band at $3439 \mathrm{~cm}^{-1}$ increases due to the $\mathrm{O}-\mathrm{H}$ stretching of sulfonic acid groups interacting with water molecules [22].

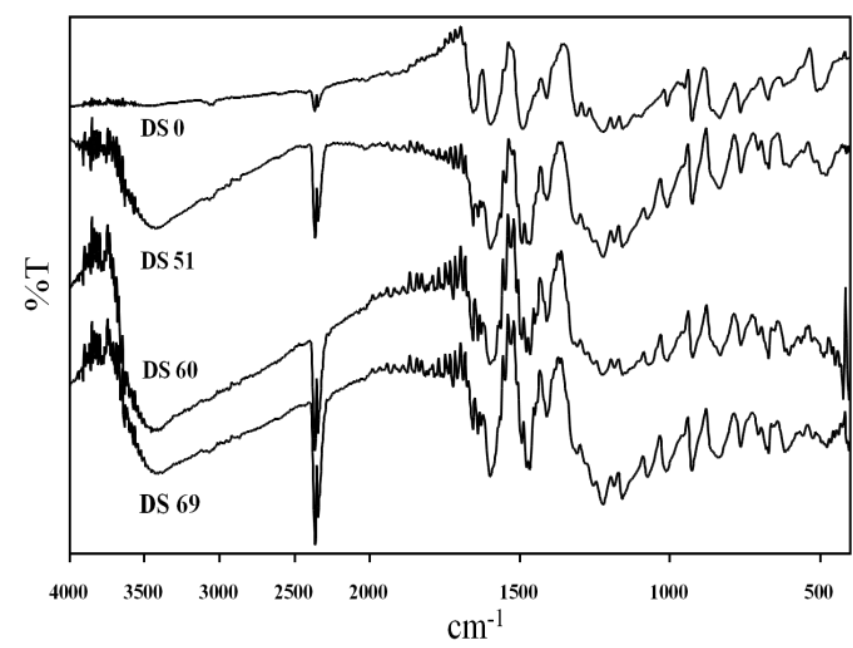

Fig. 1. Comparative FT-IR spectra of PEEK and sulfonated PEEK samples.

The values of degree of sulfonation (DS) and ion exchange capacity (IEC) of SPEEK at various reaction times are shown in Table I. The results shows that the degree of sulfonation and ion exchange capacity of SPEEK continuously increases with reaction time.

Since the physical and chemical properties of sulfonated PEEK obviously depend on the degree of sulfonation, i.e. the concentration of sulfonic groups. For example, the SPEEK is soluble in strong $\mathrm{H}_{2} \mathrm{SO}_{4}$, hot DMAc, and dimethyl sulfoxide if the DS is lower than $40 \%$, soluble in the same solvent, even at room temperature if DS over $50 \%$ and soluble in methanol and has poor chemical stability in hot water when DS is higher than 70\% [13]. Therefore, in this research, the SPEEK with $60 \%$ DS was then selected for further studies.

TABLE I: DEGREE OF SULFONATION AND IONEXCHANGE CAPACITY OF

\begin{tabular}{|l|c|c|c|c|}
\hline SPEEK & $\begin{array}{c}\text { Temperature } \\
\left({ }^{\circ} \mathrm{C}\right)\end{array}$ & $\begin{array}{c}\text { Time } \\
(\mathrm{h})\end{array}$ & $\begin{array}{c}\text { IEC } \\
\left(\mathrm{meq} \cdot \mathrm{g}^{-1}\right)\end{array}$ & $\begin{array}{c}\text { DS } \\
(\%)\end{array}$ \\
\hline SPEEK4h & 50 & 4 & 1.58 & 51 \\
\hline SPEEK6h & 50 & 6 & 1.77 & 60 \\
\hline SPEEK8h & 50 & 8 & 2.01 & 69 \\
\hline
\end{tabular}

B. Characterizations of SPEEK Nanocomposite Membranes

\section{1) Morphology}

The morphologies of SPEEK and SPEEK nanocomposite membranes were investigated using FE-SEM, the results are shown in Fig. 2. It can be observed that the surfaces of membranes are smooth. Moreover, the nanofillers seem to disperse well in SPEEK matrix.

\section{2) Crystallinity}

The crystallinity of SPEEK and SPEEK nanocomposite membranes was examined using X-ray diffraction technique. It was found that SPEEK membrane shows fully amorphous structure in which the broad signal around the reflections of crystalline SPEEK is indicative of the lack of crystallinity [23]. In addition, the SPEEK-TiO ${ }_{2}$ and SPEEK- $\mathrm{WO}_{3}$ membranes show a clear pattern of crystalline anatase $\mathrm{TiO}_{2}$ and $\mathrm{WO}_{3}$ phase within the majority amorphous polymer. While the pattern of crystalline anatase $\mathrm{SiO}_{2}$ phase in SPEEK-SiO ${ }_{2}$ membrane cannot be observed.
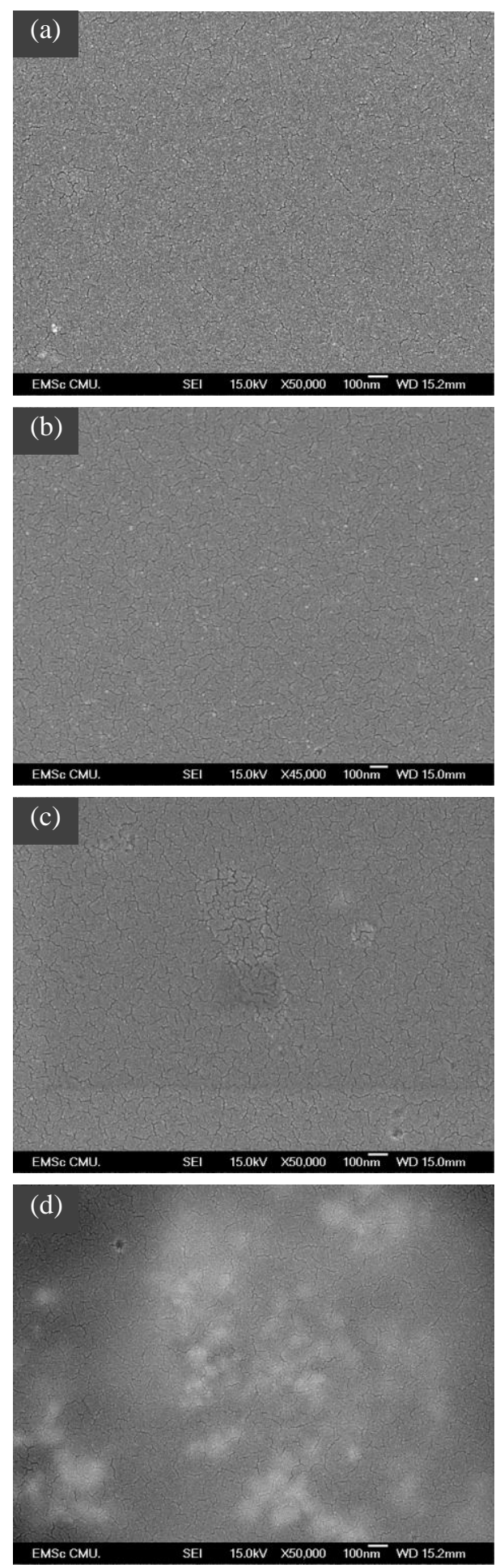

Fig. 2. FE-SEM surface images of (a) SPEEK, (b) SPEEK-SiO ${ }_{2}-5$ wt.\%, (c) SPEEK-TiO ${ }_{2}-5$ wt. $\%$. and (d) SPEEK--WO ${ }_{3}-5$ wt. $\%$.

\section{3) Thermal properties}

The thermal stability of the SPEEK and SPEEK nanocomposite membranes was analyzed using TGA as illustrated in Fig. 3. It can be observed that the membranes exhibit mainly 3 degradation steps. The first weight loss 
region $\left(30-200{ }^{\circ} \mathrm{C}\right)$ can be attributed to the evaporation of adsorbed water and residual solvent. The second weight loss region at $300-400{ }^{\circ} \mathrm{C}$ assignes to the decomposition of the sulfonic groups. In this region, the nanocomposite membranes has higher \%weight loss than the SPEEK membrane, which mainly attributes to the fact that the surface functionalized of $\mathrm{SiO}_{2}, \mathrm{TiO}_{2}$ and $\mathrm{WO}_{3}$ are also thermally decomposed at this temperature region [24]. The third weight loss with the onset temperature at about $520{ }^{\circ} \mathrm{C}$ corresponds to the degradation of the polymer backbone. In this region, it can be noticed that the presence of inorganic fillers can retard the oxidative degradation of SPEEK main, leading to an improvement of the membrane thermal stability.

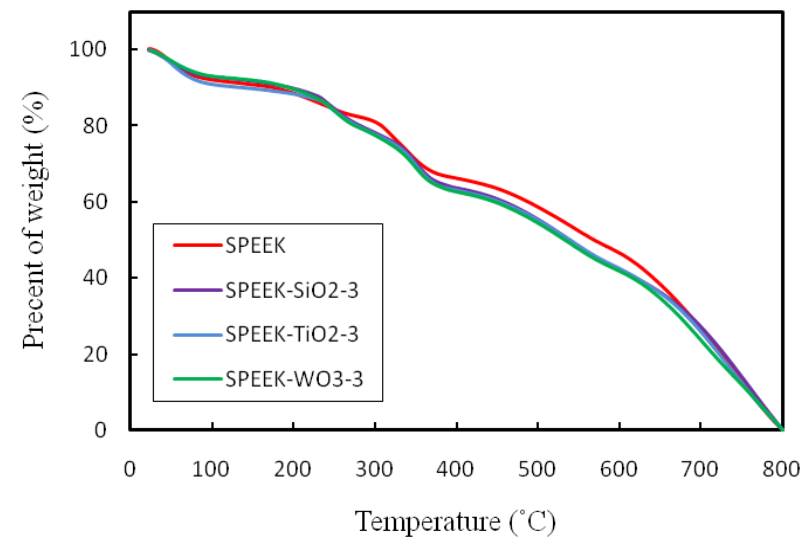

Fig. 3. TGA thermograms of SPEEK and nanocomposite membranes.

\section{4) Mechanical properties}

The mechanical properties; tensile properties, of SPEEK and SPEEK nanocomposite membranes were examined. The effects of inorganic nanofiller type and content were investigated. The results of tensile strength and elongation at break of the membranes are showed in Fig. 4 and Fig. 5, respectively.

The results show that the tensile strength of SPEEK can be improved with the addition of nanofillers. Especially, at low percentage of nanofiller (below 3 wt. \%), $\mathrm{SiO}_{2}, \mathrm{TiO}_{2}$ and $\mathrm{WO}_{3}$ nanoparticles act as reinforcing agents to improve the tensile strength of the SPEEK nanocomposite membranes [25]. At higher nanofiller content (> $3 \mathrm{wt} . \%$ ), the tensile strength of nanocomposite membranes tends to decrease, this may because of the aggregation of nanoparticles in polymer matrix. Moreover, it can be clearly observed that the SPEEK- $\mathrm{WO}_{3}$ membrane shows better tensile strength than SPEEK-SiO ${ }_{2}$ and $\mathrm{SPEEK}-\mathrm{TiO}_{2}$ membranes.

\section{5) Water uptakes study}

The water uptake values at room temperature of SPEEK and SPEEK nanocomposite membranes are showed in Fig. 6. It can be seen that the addition of $\mathrm{TiO}_{2}$ and $\mathrm{WO}_{3}$ nanofillers results in the decrease of water uptake of $\mathrm{SPEEK}^{-\mathrm{TiO}_{2}}$ and SPEEK-WO${ }_{3}$ membranes. On the other hand, the water uptake of SPEEK membrane can be improved with the addition of $\mathrm{SiO}_{2}$. In which the water uptake of SPEEK-SiO ${ }_{2}$ initially increases with increasing of $\mathrm{SiO}_{2}$ content and then continuity decreases when the $\mathrm{SiO}_{2}$ content higher than $3 \mathrm{wt} . \%$. This may comes from the general expectation that an increasing quantity of hydrophilic $\mathrm{SiO}_{2}$
Conduce to the strong interaction between the positively charged $-\mathrm{Si}-\mathrm{OH}$ groups on the $\mathrm{SiO}_{2}$ surface and $-\mathrm{SO}_{3} \mathrm{H}$ groups in SPEEK which resulting in the decrease of an average interchain distance of SPEEK [26].

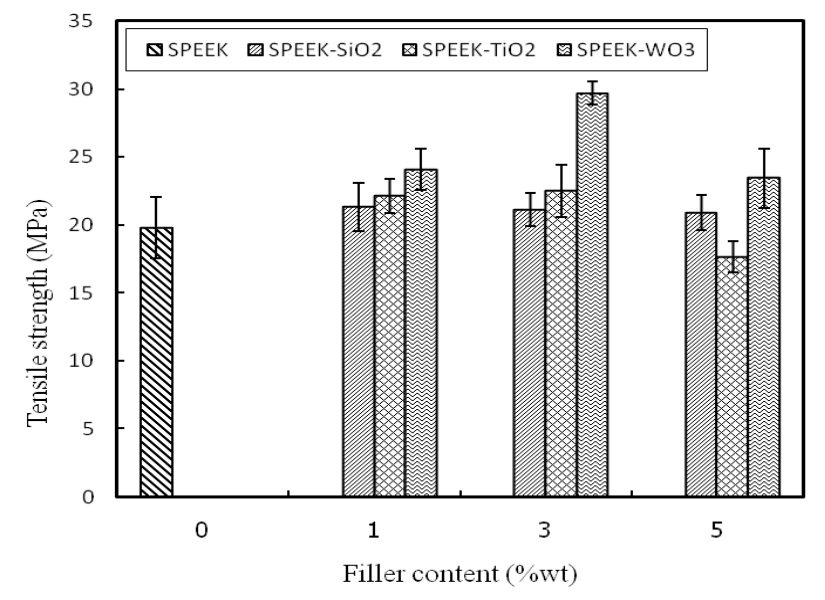

Fig. 4. Tensile strength of SPEEK and nanocomposite membranes.

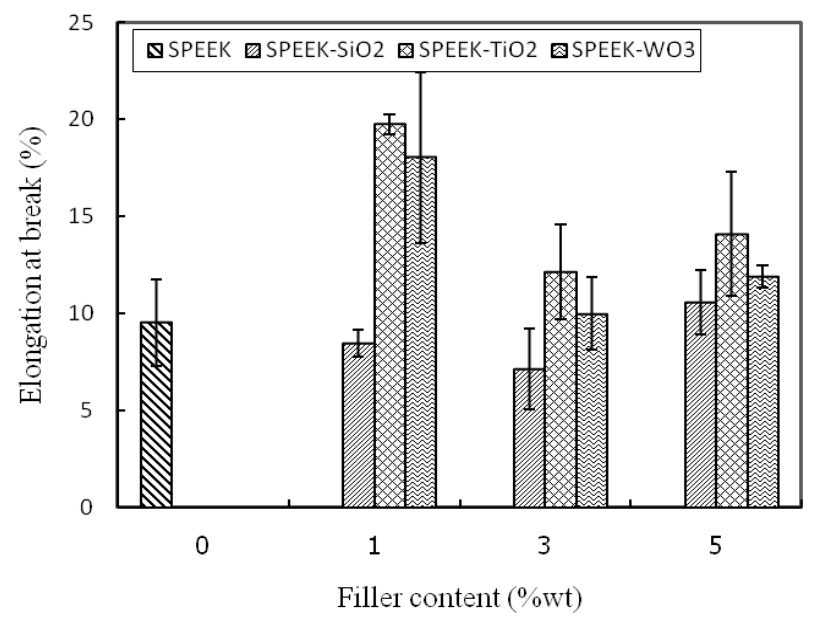

Fig. 5. Elongation at break of SPEEK and nanocomposite membranes.

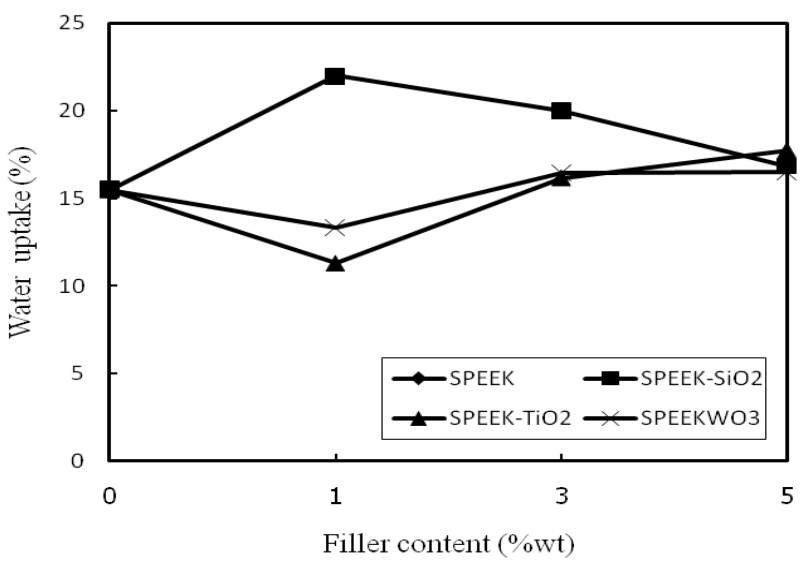

Fig. 6. Water uptake of the SPEEK and SPEEK nanocomposite membranes at room temperature.

\section{CONCLUSION}

Sulfonated poly (etheretherketone)s with various degrees of sulfonation and ion exchange capacity (IEC) were successfully prepared. SPEEK nanocomposite membranes with the addition of inorganic nanofillers; $\mathrm{SiO}_{2}, \mathrm{TiO}_{2}$ and 
$\mathrm{WO}_{3}$ were fabricated via solution casting method. The characteristic, physical, thermal and mechanical properties of the SPEEK nanocomposite membranes were systematically examined. From the experiment, it was found that the SPEEK-TiO ${ }_{2}$ and SPEEK- $\mathrm{WO}_{3}$ membranes exhibited crystalline anatase $\mathrm{TiO}_{2}$ and $\mathrm{WO}_{3}$ phase in XRD pattern. In addition, the results indicated that the addition of nanofillers can improve the thermal stability and tensile properties of the SPEEK nanocomposite membranes.

\section{ACKNOWLEDGMENT}

The authors wish to acknowledge the Center of Excellence in Materials Science and Technology, Faculty of Science and the Graduated School, Chiang Mai University for financial supports.

\section{REFERENCES}

[1] Y.-H. Seong, J. Won, S.-K. Kim, K. Namc, S.-K. Kim, and D.-W. Kim, "Synthesis and characterization of proton exchange membranes based on sulfonated poly(fluorenyl ether nitrile oxynaphthalate) for direct methanol fuel cells," International Journal of Hydrogen Energy, vol. 36, pp. 8492-8498, May 2011.

[2] S. Rena, G. Sun, C. Li, Z. Liang, Z. Wu, W. Jin, X. Qin, and X. Yang, "Organic silica/Nafion ${ }^{\circledR}$ composite membrane for direct methanol fuel cells," Journal of Power Sources., vol. 282, pp. 450-455, June 2006.

[3] K. D. Kreuer, "On the development of proton conducting polymer membranes for hydrogen and methanol fuel cells," Journal of Membrane Sciencs, vol. 185, pp. 29-39, July 2000.

[4] S. P. Nunes, B. Ruffmann, E. Rikowski, S. Vetter, and K. Richau, "Inorganic modification of proton conductive polymer membranes for direct methanol fuel cells," Journal of Membrane Sciencs, vol. 203, pp. 215-225, Jan. 2002.

[5] C. S. Karthikeyan, S. P. Nunes, L. A. S. A. Prado, M. L. Ponce, H. Silva, B. Ruffmann, and K. Schulte, "Polymer nanocomposite membranes for DMFC application," Journal of Membrane Sciencs., vol. 254, pp. 139-146, April 2005.

[6] V. S. Silva, B. Ruffmann, S. Vetter, A. Mendes, L. M. Madeira, and S. P. Nunes, "Characterization and application of composite membranes in DMFC," Catalysis Today, vol. 104, pp. 205-212, April 2005.

[7] V. S. Silva, S. Weisshaar, R. Reissner, B. Ruffmann, S. Vetter, A. Mendesb, L. M. Madeira, and S. Nunes, "Performance and efficiency of a DMFC using non-fluorinated composite membranes operating at low/medium temperatures," Journal of Power Sources., vol. 145, pp. 485-494, April 2005.

[8] S. Ren, C. Li, X. Zhaob, Z. Wu, S. Wang, G. Sun, Q. Xin, and X. Yang, "Surface modification of sulfonated poly(ether ether ketone) membranes using Nafion solution for direct methanol fuel cells," Journal of Membrane Sciencs., vol. 247, pp. 59-63, Sep. 2004.

[9] X. Li, D. Chen, D. Xu, C. Zhao, Z. Wang, H. Lu, and H. Na, "SPEEKK/polyaniline (PANI) composite membranes for direct methanol fuel cell usages," Journal of Membrane Sciencs, vol. 275, pp. 134-140, Oct. 2005.

[10] J. Roeder, H. Silva, S. P. Nunes, and A. T. N. Pires, "Mixed conductive blends of SPEEK/PANI," Solid State Ionics, vol. 176, pp. 1411-1417, March 2005.

[11] S. M. J. Zaidi, "Preparation and characterization of composite membranes using blends of SPEEK/PBI with boron phosphate," Electrochimica Acta, vol. 50, pp. 4771-4777, March 2005.

[12] C. Li, G. Suna, S. Ren, J. Liu, Q. Wang, Z. Wu, H. Sun, and W. Jin, "Casting Nafion-sulfonated organosilica nano-composite membranes used in direct methanol fuel cells," Journal of Membrane Sciencs, vol. 272, pp. 50-57, Sep. 2005.

[13] J. H. Changa, J. H. Park, G.-G. Park, C.-S. Kimb, and O. O. Parka, "Proton-conducting composite membranes derived from sulfonated hydrocarbon and inorganic materials," Journal of Power Sources, vol. 124, pp. 18-25, May. 2003.
[14] B. Ruffmann, H. Silvaa, B. Schulte, and S. P. Nunes, "Organic/inorganic composite membranes for application in DMFC," Solid State Ionics, vol. 162-163, pp. 269-275, Jan. 2003.

[15] C. H. Lee, S. Y. Hwang, J. Y. Sohn, H. B. Park, J. Y. Kim, and Y. M. Lee, "Water-stable crosslinked sulfonated polyimide-silica nanocomposite containing interpenetrating polymer network," Journal of Power Sources, vol. 163, pp. 239-348, Oct. 2006.

[16] A. Saccà, I. Gatto, A. Carbone, R. Pedicini, and E. Passalacqua, "ZrO2-Nafion composite membranes for polymer electrolyte fuel cells (PEFCs) at intermediate temperature," Journal of Power Sources, vol. 163, pp. 47-51, Feb. 2006.

[17] P. Bébin, M. Caravanier, and H. Galiano, "Nafion ${ }^{\circledR} /$ clay$^{-} \mathrm{SO}_{3} \mathrm{H}$ membrane for proton exchange membrane fuel cell application," Journal of Membrane Sciencs., vol. 278, pp. 35-42, Dec. 2005.

[18] A. S. Aricò, V. Baglio, A. Di Blasi, E. Modica, P. L. Antonucci, and V. Antonucci, "Surface properties of inorganic fillers for application in composite membranes-direct methanol fuel cells," Journal of Power Sources, vol. 128, pp. 113-118, Sep. 20003.

[19] R. Jiang, H. R. Kunz, and J. M. Fenton, "Investigation of membrane property and fuel cell behavior with sulfonated poly (ether ether ketone) electrolyte: Temperature and relative humidity effects," Journal of Power Sources, vol. 150, pp. 120-128, May 2005.

[20] H. Li, Z. Cui, C. Zhao, J. Wu, T. Fu, Y. Zhang, K. Shao, H. Zhang, H. $\mathrm{Na}$, and W. Xing, "Synthesis and property of a novel sulfonated poly(ether ether ketone) with high selectivity for direct methanol fuel cell applications," Journal of Membrane Sciencs, vol. 343, pp. 164-170, July 2009.

[21] S. Zhong, X. Cui, H. Cai, T. Fu, K. Shao, and H. Na, "Crosslinked SPEEK/AMPS blend membranes with high proton conductivity and low methanol diffusion coefficient for DMFC applications," Journal of Power Sources, vol. 168, pp. 154-161, March 2007.

[22] N. Intaraprasit and P. Kongkachuichay, "Preparation and properties of sulfonated poly(ether ether ketone)/Analcime composite membrane for a proton exchange membrane fuel cell (PEMFC)," Journal of the Taiwan Institute of Chemical Engineers, vol. 42, pp. 190-195, May 2010.

[23] M. L. D. Vona, E. Sgreccia, A. Donnadio, M. Casciola, J. F. Chailan, G. Auer, and P. Knauth, "Composite polymer electrolytes of sulfonated poly-ether-ether-ketone (SPEEK) with organically functionalized Ti $i_{02}$," Journal of Membrane Sciencs., vol. 369, pp. 536-544, Dec. 2010.

[24] C. H. Rhee, H. K. Kim, H. Chang, and J. S. Lee, "Nafion/Sulfonated Montmorillonite Composite: A New Concept Electrolyte Membrane for Direct Methanol Fuel Cells," Chem. Mater, vol. 17, no. 7, pp. 1691-1697, Oct. 2005.

[25] E. Kontou and M. Niaounakis, "Thermo-mechanical properties of LLDPE/ $/ \mathrm{SiO}_{2}$ nanocomposites," Polymer, vol. 47, pp. 1267-1280, Jan. 2006.

[26] C. H. Lee, K. A. Min, H. B. Park, Y. T. Hong, B. O. Jung, and Y. M. Lee, "Sulfonated poly(arylene ether sulfone)-silica nanocomposite membrane for direct methanol fuel cell (DMFC)," Journal of Membrane Sciencs, vol. 303, pp. 258-266, July 2007.

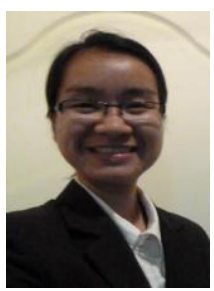

S. Sonpingkam was born in Lampang (Thailand) on July 30,1988 . She received her bachelor's degree in Chemistry from University of Phayao, Thailand. At present, she is doing master's degree in Industrial Chemistry from Chiang Mai University, Thailand under the supervision of Dr. Datchanee Pattavarakorn.

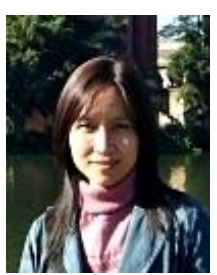

D. Pattavarakorn received Ph.D. degree in Polymer Science from the Petroleum and Petrochemical College, Chulalongkorn University, Bangkok, Thailand in 2005. In present, she is the lecturer at Department of Industrial Chemistry, Faculty of science, Chiang Mai University, Chiang Mai, Thailand in the field of Polymer Technology. Her research interest includes conductive and electroactive polymers, biodegradation plastics and 